Volume 4, Issue 2, 81 - 89.

ISSN: 2165-8714

http://www.eu-jer.com/

\title{
A Critical Study of the Subject of Education at Graduate Level in Karachi
}

\author{
Anila Fatima Shakil \\ Jinnah University for Women, \\ PAKISTAN
}

\author{
Waqar Un Nisa Faizi* \\ Shaheed Benazir Bhutto \\ Women University, \\ PAKISTAN
}

\author{
Syed Munir Ahmed \\ University of Peshawar, \\ PAKISTAN
}

\author{
Farkhanda Jabeen \\ Shaheed Benazir Bhutto \\ Women University, PAKISTAN
}

\begin{abstract}
This research is a critical study of instructional topics and their effectiveness in the subject of Education taught in colleges at graduate level vis-à-vis our current needs and the advancements in this field through research in all over the world. It also emphasizes the importance of curriculum review and revision for overcoming obstacles in curriculum development. The methodology of this study was a survey based or enquiry into the need and scope of subject of Education in our society. Secondly the existing curriculum had been analyzed form data interpretation. The target population for this study is the teachers and the students of all those government and private colleges in Karachi that offer Education as a subject at graduate level. Out of those, 24 government colleges and 7 private colleges had been selected for the survey questionnaire. 607 respondents including 57 teachers and 550 students were randomly selected from the colleges. The questionnaires were used as a research tool. The collected data was interpreted and evaluated through chi-square statistical tool. In the light of results recommendations were presented to update the curriculum and adjust to the changing trends of this modern and growing world.
\end{abstract}

Keywords: Critical study, graduate level, instruction

To cite this article: Shakil, A.F, Faizi, W.U.N., Ahmed, S.M. \& Jabeen, F. (2015). A Critical Study of the Subject of Education at Graduate Level in Karachi. European Journal of Educational Research, 4(1), 81-89. doi: 10.12973/eu-jer.4.2.81

\section{Introduction}

Introduction: The child of today is the builder of tomorrow. No more important public service, therefore, exists then to ensure that when children leave educational institutions as young adults, they are empowered with required knowledge and skills to be aware and successful members of society. This reality alone tells the importance of education has for an individual and the group. Education in this context has two important features: It provides personal orientation in an increasingly complex world; and it facilitates participation in social life. Therefore, education must create the prerequisites that are necessary for teaching, knowledge and skills. Also, it must counteract social and professional marginalization in the light of ever higher and constantly new qualification requirements. These personal and public aspects of education for any group or nation are attended to through the policy. An educational policy leads to the formation of desired goals, which then shape the curriculum. Curriculum as a balanced, comprehensive written plan that becomes a process, through textbooks, instruction and assessment mechanism, provides knowledge useful for a developing society, inculcating independent and critical thinking, creating skills, problem solving skills and attitudes relevant to real life situations. Kerr John, (1968) defined curriculum as "all the learning which is planned and guided by the school, whether it is carried on in groups or individually, inside or outside the school. Beauchamp G.A. (1968) also defined curriculum "as a design of a social group for the educational experiences of their children in school". Curriculum is a plan that includes experiences for the learners. Curriculum is not only a means to achieve the ends of education but also lays the basis for increasing the ability of students for becoming active, participating adults. In this sense, active participation means that one learns some real skills and knowledge, which allows one to take part in adding to the general social betterments. Therefore, the importance to revise and update any curricula is essential. There has to be a regular, detailed and rigorous process to review specific benchmarks, suggested material and books, pedagogical trends and assessments methods. This process is fundamental to all subjects across all grade levels. However, the importance of curriculum development and review is crucial for the subject of Education.

As the subject of "logic" is considered as the mother of all sciences, the subject of education is the foundation of entire Teaching-Learning System. If we look at the structure of our education system, it necessitates such knowledge, skills and attitudes that can form a strong basis to fortify any system. Educational research, child psychology, planning and administration, classroom and behavior management, pedagogical strategies, assessment tools, character building, critical thinking and decision making skills, all are encapsulated in the subject of Education. The rationale to do so is the fact that for a large literate majority of Pakistan, and even world over, decent education should be defined as

\footnotetext{
* Corresponding author:

Waqar Un Nisa Faizi, Shaheed Benazir Bhutto Women University, Pakistan

E-mail: faizi5120@hotmail.com
} 
acquiring a graduate degree. In this case the curriculum should be aligned in such a way that it should equip individuals with the knowledge and skills to be creative, productive and successfully survive in this increasingly complex world, so as to creating opportunity for themselves and others. Keeping in view the importance of graduate studies, the curriculum of Education in colleges should aim at holistic development of learners. It should encompass strategic selection and sequencing of information to be taught and features of instructional design that includes what to teach, when to introduce skills and concepts, and how to integrate standards, procedures and strategies to facilitate learning.

The study had the following aims:

- Assess the level of congruency between learning outcomes at graduate level and stated national goals.

- Identify the limitations of existing curriculum of Education at the graduate level.

- Highlight incompatibility between curriculum and needs of both educators and learners.

- Demonstrate understanding of the process of curriculum revision and development and its implications on the existing quality of the subject of Education.

- Document lack of practical approaches in curriculum for equipping future professional with the desired knowledge, skills and attitudes.

\section{Literature Review}

We are living in an age characterized by challenges, where nations must not only accept the challenges of today but also confront those expected to come in future. Such groundwork can be done only through investing in our youth and making them responsible citizens of tomorrow. To meet these challenges and realize ideals, our education system has to work at full potential, providing services of highest quality. The utmost contribution of the system in this regard is to develop a curriculum that is comprehensive, rigorous, futuristic and consistent with the needs of the nation. Our desires and attempt to develop and refine individuals and intellects have always been achieved through good education and educational systems. There are many variables that help create such systems; however, curriculum plays a pivotal role among all. Curriculum sets the direction and focus of that journey an individual takes to reach his/her full potential. Therefore, a curriculum should be dynamic and flexible enough to cater to the needs of a variety of learners. It should expose them to a range of knowledge domains and help acquire skills that align with the goal of learners becoming independent, productive individuals with global perspective in existing as well as future environments. Since curriculum has diverse needs to cater to, its scope is almost infinite. It relates to everything and anything that is essential to the present and future needs of individual learners. It covers all knowledge required for progressive acquisition and ways to help learners to access and process knowledge through skills of collecting, analyzing and synthesizing information. Dash (2007) states that the scope of curriculum entails a search for answers to two basic questions: Who should decide on content? And what content should be included? The first question invites a variety of stakeholders from educationists, members of Curriculum Bureau and sociologists to parents, subject specialists, and psychologists. These stakeholders, when selecting content and instructional topics, should keep in view the knowledge and information related to lives of learners in their homes, social environment, practical needs and work places.

The importance of clear, valid and effective curriculum has been emphasized at the outset by educationist and researchers. Marsh (1995), Raymont T. (2005), Purkait B.R. (2006), C. McGee (1997) and others have stated guiding principles for academicians and writers to keep in mind when working on curriculum related documents such as content, instructional topics, pedagogical approaches and assessment methods. The principles of curriculum are as follows:

- It should include the totality of experiences that learners faced during their studies and help in the evolution of balanced personality

- It must have child centered approach and all activities should align to learners" needs, abilities and interests

- It should foster creativity and create opportunities to nurture innate talents. This has been particularly emphasized by Raymont (2005).

- It should have the social development aspect to not only help in citizenship training but also to facilitate individuals in fulfilling societal demands and for better social adjustment

- It should create opportunities of understanding and appreciating ones and nations roots and heritage

- It should have a modern and dynamic outlook and approach to prepare todays learners for tomorrow, meeting their future social and professional needs.

- It should have focus, relevancy and integration for learners to optimize the benefits.

- It should have a regular and rigorous process of review and revision to meet the demands of ever changing world.

Curriculum development is a rigorous, comprehensive process that involves much more than selection of content or instructional topics. The process also includes stating broader aims and expected outcomes across grades, identifying appropriate textbooks, accessories needed for using them in classrooms and assessment tools. According to Hunkin (1980) curriculum development implies a fundamental recasting of educational process as a whole; a spring cleaning of existing school content and revamping of teaching methods, exemplifying a belief in the need for corporate planning. This leads to say that curriculum development 
is a dynamic process and therefore, should be viewed as an ongoing process, always in a state of planned changes.

The process of curriculum development is complex and starts with establishing a vision and identification of goals by the group, community or nation. This vision and goals then are weaved into a plan that coordinates in an orderly manner the elements of time, space, material, equipment and personnel to achieve desired aims. This process starts at the highest level i.e. Ministry or Bureau and goes down to the last link in the chain i.e. the learner who is the main beneficiary. According to Singh (2007) the basic requirements for developing a curriculum are to identify the intended learners and their needs, to formulate objectives and intended learning outcomes, to specify and justify what should be taught to the intended learner, to organize the selected content appropriately and to evaluate the learning outcomes. Each one of these steps is critical and requires utmost attention and deliberation. These steps are:

- Establishing a vision

- Identifying goals and determining objectives

- Relating goals to curriculum

- Curriculum mapping

- Needs assessment

- Instructional planning

- Selection and organization of content \& learning experience

- Implementation of curriculum

- Evaluation of curriculum

The complexity of curriculum development has increased manifolds in recent years due to rapid social, scientific and technological changes that have entirely changed man's outlook of life. The skills and knowledge fields of past, even those a decade old have become obsolete in the wake of new discoveries and researches. What used to have scope and practicality has become outdated. Things around us are digitizing at an extremely fast pace and for the simplest of procedures you require new skills.

According to Charan (2003) a complete curriculum would consist of a framework with all slots filled with excellent, highly interactive, research based materials that take full advantage of data and modeling tools. And for this, curriculum review at every level become an essential need; especially at graduate level as it play an important role not only to select better professions but also to help individuals adjusting well within different environments. Therefore, the subject matter or the instructional material should focus the learner and his needs. Massie (2002) defines this through an interesting metaphor. He sees learners or graduates as the actual product rather than the curriculum. Thus, first we must define our product and its standards. Then we should produce the product and assure its quality. The criteria of revision require that a curriculum be approached from the outside looking in by focusing the product instead of the process which produces it. This entails a very focused and diligent approach to the process of curriculum review and revision.

Since curriculum reviews provide a systematic method for acquiring accurate and broad-based internal and external feedback regarding the effectiveness and relevancy of a program's curriculum, it must have clear deliverables. Typically, a review process is initiated after every three years and works around these set of deliverables: a) revised program aim and goals which can either be general e.g. program aim and goals, or on the specific e.g. individual course competencies, or both; b) revised program map and outline which may lead to dropping entire courses from the program, adding new courses, and/or reducing or increasing the number of credits or hours for a course in the program; and c) a final report, complete with internal and industry feedback, recommendations and implementation plan. In Pakistan, focused work on curriculum planning picked momentum in the last six to eight years. Presently major focus of work has been around primary level and graduate level. The reason for targeting primary and graduate education is due to the fact that these two levels are crucial points in the lives of individuals. Graduate education aims at the advance training of young people of serious purpose who have had at least twelve years of previous schooling and possess enough intellectual ability to carry on courses in higher education. Therefore, graduate level education must equip learners to cope with the real world. It should attempt to create proper work habits, clarity and independence of thoughts, a sense of honesty and justice, in their personal, social and professional dealings and a lifelong desire for learning. These individuals eventually provide national leadership at various levels and in varied fields of life. At his level, whatever investments are done in individuals, have immediate returns in form of socio-economic development and progress of the country as well for individuals. This has made education at graduate level an important factor on global educational map. To meet international standard of quality, our colleges and universities have to take up a two prong approach: there should be high caliber experts and research professors to guide and groom learners; and the curriculum must be regularly reviewed and restructured to incorporate modern theories and researches, emerging knowledge domains, and cutting edge concepts.

In recent years, Ministry of Education has taken up major initiatives to develop curriculum for the BS (Bachelors of Studies) and MS (Masters of Studies) Degree Programs. However, due attention is not given to 2-year graduate programs. The BA is still not aligned with international standards thus, leaving students at a disadvantage. And the case of subject of Education in particular seems to have been neglected the most. Though Education as a subject got recognition and focus in 1972 in Pakistan. The education policy of that year identified and introduced Education as an optional 
subject for Higher Secondary level. Later it was offered for studying at graduation level and eventually at post graduate level in early 1980s. The rationale behind this step was to have qualified individuals that can strengthen the framework of our education system. Studying Education provides one with the opportunity of understanding, analyzing and examining the subject from multiple aspects: the philosophical grounding, societal needs, systems and procedure, political and socio-economic implications, and above all the possibilities for shaping future. It equips professionals of the field to play a pivotal role in increasing the possibilities of progress and development, both at individuals and group level, for a society. In the developed world Education is the most growing and researchable field in Social Sciences. With every passing year interest of learners in the subject is growing as this is the only field whose scope of study ranges from formation and management of human behavior and development of skills and attitudes to identification of constructive approaches to develop and maintain the fabric of society.

Through the study of this subject we can evaluate the educational system and compare characteristics and qualities of our system to others for improvement and modification. It gives awareness of new concepts, changing technology and helps in opening of new fields and ways for individuals. As mentioned earlier, the Ministry of Education has been making efforts to bring improvement at various levels of education, particularly at graduate and postgraduate level. The efforts however, have not been carried further to the BA program. The present course of Education at BA was last reviewed along with other subjects in 1992 but the revision of Education was on a limited scale (Isani \& Virk, 2003). This inadequate revision and the growth and expansion of the world in last two decades have left many gaps to be filled in. The purpose of this study was to look at effectiveness of current instructional topics offered in Education at BA level vis-à-vis relevancy to modern world and its needs, application in real life, skill development, career scopes, and leadership capacity building. As we understand, the aim of education at graduate level is to help individuals to become enlightened, thinking men and women and competent professionals who can make aware decisions and bring positive change in their lives as well of others. Therefore, like other graduates, these outcomes are also expected of those studying Education. However, the instructional topics, course methodology and assessment procedures of the subject of Education at BA level give an impression that is otherwise. Most instructional topics have outdated or incomplete information and do not take into account relevant researches. This combined with a predominantly lecture-based, rote learning approach results in failure to achieve the outcomes expected both from the curriculum standpoint and that of individuals' desires. This research analyzed the instructional topics to explore the extent to which the current course offered at BA level leads to develop leadership and creativity, critical thinking and analytical skills, and problem solving ability in graduate-learners. For this the research also looked at variety in course methodology that can lead to acquiring above said skills. It may be included fieldwork, projects, case study method, experimentation, etc. to give learners hands-on experience and opportunity to apply the knowledge gained. The skills and methodologies were part of the research questionnaire as well to get support-data for analysis. The researcher has critically examined the effectiveness of the topics along with the sub-topics, which are taught in 2-year BA program. The following instructional topics are taught in part I and II:

\section{PART I}

- Teacher and Student

- Curriculum Planning

- Lesson Planning

- Freedom and Discipline

- Educational Administration of Pakistan

\section{PART II}

- Philosophical and Religious Foundations of Education

- Psychological Foundation of Education

- Sociological Foundation of Education

- Education in Pakistan - Policies and Steps

- Educational Movements of South Asia

Apart from the researchers' analysis, the lack of exposure to higher order skills at graduate level and the need for revision to include modern researches and introduce interactive, active learning strategies within the instructional topics, these concerns and expectations have also been expressed by the target population of this research. The learners feel that today they live in a society where knowledge and information are ever more complex and ever more quickly becomes redundant, which makes it increasingly important for them to have requisite skills to make better choices for themselves and others based on logical reasoning, critical and analytical thinking. Therefore, they must be engage in higher-order learning skills within the instructional topics during their studies to successfully deal with their present and future needs.

\section{Methodology}

This study was a mixed-methods research design, incorporating both qualitative and quantitative research approaches based on survey. It was a comprehensive analysis of academic needs of 31 government and private colleges, where the subject Education has been taught at the graduate level. 57 teachers and 550 students were the sample of the study. In addition to using percentages for deciding about the significance of questions, chi-square was also used. 
Results
Results of the study were summarized in three tables below.

Table 1. The first table shows the views of teachers and students (using the chi-square test) that to what extent curriculum promotes the required qualities among students.

\begin{tabular}{|c|c|c|c|c|c|c|}
\hline & & & STUDENTS & TEACHERS & STUDENTS & TEACHERS \\
\hline & STATEMENTS & CHI-SQUARE & $\begin{array}{l}\text { Governme } \\
\text { nt Colleges }\end{array}$ & $\begin{array}{l}\text { Private } \\
\text { Colleges }\end{array}$ & $\begin{array}{c}\text { Government } \\
\text { Colleges }\end{array}$ & $\begin{array}{l}\text { Private } \\
\text { Colleges }\end{array}$ \\
\hline 1 & $\begin{array}{l}\text { Give opportunity to } \\
\text { develop leadership skills }\end{array}$ & $\begin{array}{l}\text { Table Value }(0.5) \\
\text { Calculated Values } \\
\text { Null Hypothesis }\end{array}$ & $\begin{array}{c}9.488 \\
139.529 \\
\text { Rejected }\end{array}$ & $\begin{array}{c}9.488 \\
63.936 \\
\text { Rejected }\end{array}$ & $\begin{array}{c}9.488 \\
12.221 \\
\text { Rejected }\end{array}$ & $\begin{array}{c}9.488 \\
5.498 \\
\text { Accepted }\end{array}$ \\
\hline 2 & $\begin{array}{l}\text { Help in promoting } \\
\text { problem solving skills }\end{array}$ & $\begin{array}{c}\text { Table Value }(0.5) \\
\text { Calculated Values } \\
\text { Null Hypothesis }\end{array}$ & $\begin{array}{c}9.488 \\
116.154 \\
\text { Rejected } \\
\end{array}$ & $\begin{array}{c}9.488 \\
69.876 \\
\text { Rejected } \\
\end{array}$ & $\begin{array}{c}9.488 \\
16.221 \\
\text { Rejected } \\
\end{array}$ & $\begin{array}{c}9.488 \\
12.998 \\
\text { Rejected }\end{array}$ \\
\hline 3 & $\begin{array}{l}\text { Share latest trends and } \\
\text { ideas }\end{array}$ & $\begin{array}{l}\text { Table Value }(0.5) \\
\text { Calculated Values } \\
\text { Null Hypothesis }\end{array}$ & $\begin{array}{c}9.488 \\
104.206 \\
\text { Rejected }\end{array}$ & $\begin{array}{c}9.488 \\
59.452 \\
\text { Rejected }\end{array}$ & $\begin{array}{c}9.488 \\
53.776 \\
\text { Rejected }\end{array}$ & $\begin{array}{c}9.488 \\
8.832 \\
\text { Accepted }\end{array}$ \\
\hline 4 & $\begin{array}{l}\text { Promote memorization } \\
\text { of information }\end{array}$ & $\begin{array}{c}\text { Table Value }(0.5) \\
\text { Calculated Values } \\
\text { Null Hypothesis }\end{array}$ & $\begin{array}{c}9.488 \\
37.27 \\
\text { Rejected } \\
\end{array}$ & $\begin{array}{c}9.488 \\
40.179 \\
\text { Rejected } \\
\end{array}$ & $\begin{array}{c}9.488 \\
27.332 \\
\text { Rejected } \\
\end{array}$ & $\begin{array}{c}9.488 \\
10.498 \\
\text { Rejected } \\
\end{array}$ \\
\hline 5 & $\begin{array}{l}\text { Provide educational } \\
\text { case studies in Pakistan } \\
\text { scenarios for debate and } \\
\text { discussion }\end{array}$ & $\begin{array}{l}\text { Table Value }(0.5) \\
\text { Calculated Values } \\
\text { Null Hypothesis }\end{array}$ & $\begin{array}{c}9.488 \\
34.153 \\
\text { Rejected }\end{array}$ & $\begin{array}{c}9.488 \\
30.482 \\
\text { Rejected }\end{array}$ & $\begin{array}{c}9.488 \\
11.555 \\
\text { Rejected }\end{array}$ & $\begin{array}{c}9.488 \\
17.998 \\
\text { Rejected }\end{array}$ \\
\hline 6 & $\begin{array}{l}\text { Helpful in the } \\
\text { development of } \\
\text { research skills }\end{array}$ & $\begin{array}{l}\text { Table Value }(0.5) \\
\text { Calculated Values } \\
\text { Null Hypothesis }\end{array}$ & $\begin{array}{c}9.488 \\
29.607 \\
\text { Rejected } \\
\end{array}$ & $\begin{array}{c}9.488 \\
55.573 \\
\text { Rejected } \\
\end{array}$ & $\begin{array}{c}9.488 \\
21.332 \\
\text { Rejected } \\
\end{array}$ & $\begin{array}{c}9.488 \\
7.164 \\
\text { Accepted } \\
\end{array}$ \\
\hline 7 & $\begin{array}{l}\text { Give opportunity for the } \\
\text { application of } \\
\text { knowledge }\end{array}$ & $\begin{array}{l}\text { Table Value }(0.5) \\
\text { Calculated Values } \\
\text { Null Hypothesis }\end{array}$ & $\begin{array}{c}9.488 \\
60.232 \\
\text { Rejected }\end{array}$ & $\begin{array}{c}9.488 \\
76.967 \\
\text { Rejected }\end{array}$ & $\begin{array}{c}9.488 \\
12.443 \\
\text { Rejected }\end{array}$ & $\begin{array}{c}9.488 \\
12.998 \\
\text { Rejected }\end{array}$ \\
\hline 8 & $\begin{array}{l}\text { Provide scientific based } \\
\text { information about } \\
\text { health education }\end{array}$ & $\begin{array}{l}\text { Table Value (0.5) } \\
\text { Calculated Values } \\
\text { Null Hypothesis }\end{array}$ & $\begin{array}{c}9.488 \\
34.569 \\
\text { Rejected }\end{array}$ & $\begin{array}{c}9.488 \\
38.422 \\
\text { Rejected }\end{array}$ & $\begin{array}{c}9.488 \\
14.887 \\
\text { Rejected }\end{array}$ & $\begin{array}{c}9.488 \\
12.998 \\
\text { Rejected }\end{array}$ \\
\hline 9 & $\begin{array}{l}\text { Integrate IT among } \\
\text { student }\end{array}$ & $\begin{array}{l}\text { Table Value }(0.5) \\
\text { Calculated Values } \\
\text { Null Hypothesis }\end{array}$ & $\begin{array}{c}9.488 \\
81.01 \\
\text { Rejected } \\
\end{array}$ & $\begin{array}{c}9.488 \\
38.845 \\
\text { Rejected } \\
\end{array}$ & $\begin{array}{c}9.488 \\
3.776 \\
\text { Accepted } \\
\end{array}$ & $\begin{array}{c}9.488 \\
12.164 \\
\text { Rejected } \\
\end{array}$ \\
\hline 10 & $\begin{array}{l}\text { Help in better job } \\
\text { placement of graduate } \\
\text { in respective field }\end{array}$ & $\begin{array}{c}\text { Table Value }(0.5) \\
\text { Calculated Values } \\
\text { Null Hypothesis } \\
\end{array}$ & $\begin{array}{c}9.488 \\
23.4 \\
\text { Rejected } \\
\end{array}$ & $\begin{array}{c}9.488 \\
54.482 \\
\text { Rejected } \\
\end{array}$ & $\begin{array}{c}9.488 \\
8.221 \\
\text { Accepted } \\
\end{array}$ & $\begin{array}{c}9.488 \\
22.998 \\
\text { Rejected } \\
\end{array}$ \\
\hline
\end{tabular}

As the above table shows, majority of the teachers and students think that curriculum do not provide opportunity to develop leadership, research and problem solving skills nor share latest trends, integrate IT and scientific based information about health education neither application of knowledge and placement in better jobs. It only promote memorization of information without providing educational case studies in Pakistan scenarios for debate and discussion among students 
Table 2. The second table shows the views of teachers and students (using the chi-square test) that to what extent curriculum provide opportunities for advancement in their respective fields for them.

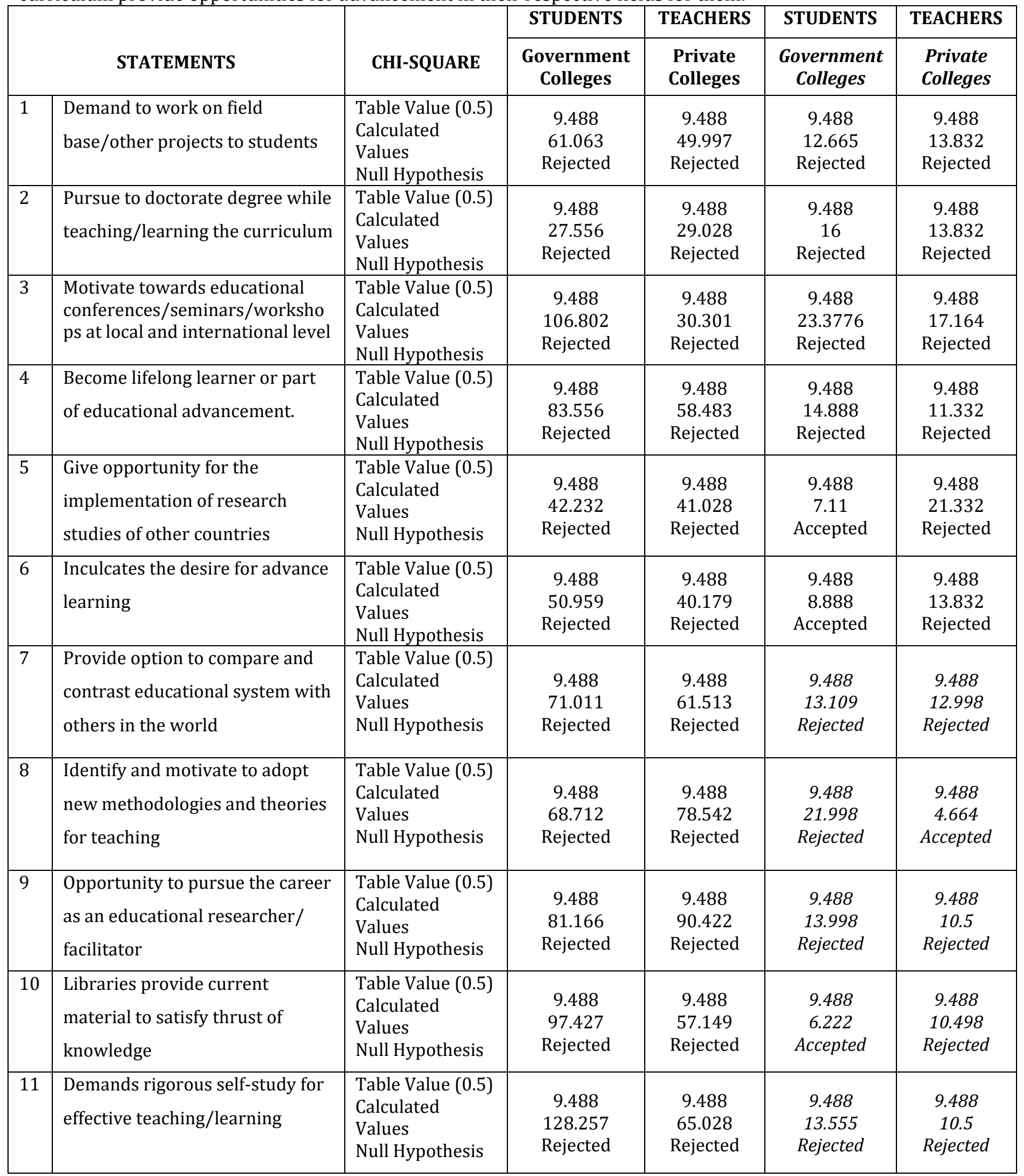

As the above table shows, majority of the teachers and students think that curriculum do not motivate them towards educational conferences/seminars/workshops nor become lifelong learner neither motivate to pursue doctorate degree or be a researcher/facilitator. It do not demand rigorous self-study, work on field base/other projects, implementation of research studies and new methodologies/theories as well as opportunity to 
compare our educational system to other countries. It do field at local or international level. not help them to contribute productively in respective

Table 3. The third table shows the views of teachers and students (using the chi-square test) that to what extent curriculum need constant review and revision to meet globalized world of today.

\begin{tabular}{|c|c|c|c|c|c|c|}
\hline & \multirow[b]{2}{*}{ STATEMENTS } & \multirow[b]{2}{*}{ CHI-SQUARE } & STUDENTS & TEACHERS & STUDENTS & TEACHERS \\
\hline & & & $\begin{array}{l}\text { Governme } \\
\text { nt Colleges }\end{array}$ & $\begin{array}{l}\text { Private } \\
\text { Colleges }\end{array}$ & $\begin{array}{c}\text { Government } \\
\text { Colleges }\end{array}$ & $\begin{array}{l}\text { Private } \\
\text { Colleges }\end{array}$ \\
\hline 1 & $\begin{array}{l}\text { Give information of } \\
\text { current pedagogical } \\
\text { aspects }\end{array}$ & $\begin{array}{c}\text { Table Value }(0.5) \\
\text { Calculated Values } \\
\text { Null Hypothesis } \\
\end{array}$ & $\begin{array}{c}9.488 \\
70.569 \\
\text { Rejected } \\
\end{array}$ & $\begin{array}{c}9.488 \\
49.392 \\
\text { Rejected } \\
\end{array}$ & $\begin{array}{c}9.488 \\
19.998 \\
\text { Rejected } \\
\end{array}$ & $\begin{array}{c}9.488 \\
23.832 \\
\text { Rejected } \\
\end{array}$ \\
\hline 2 & $\begin{array}{l}\text { Comparable to } \\
\text { international standards } \\
\text { in term of knowledge } \\
\text { and skills }\end{array}$ & $\begin{array}{l}\text { Table Value }(0.5) \\
\text { Calculated Values } \\
\text { Null Hypothesis }\end{array}$ & $\begin{array}{c}9.488 \\
85.427 \\
\text { Rejected }\end{array}$ & $\begin{array}{c}9.488 \\
45.755 \\
\text { Rejected }\end{array}$ & $\begin{array}{c}9.488 \\
10.332 \\
\text { Rejected }\end{array}$ & $\begin{array}{c}9.488 \\
12.164 \\
\text { Rejected }\end{array}$ \\
\hline 3 & $\begin{array}{l}\text { Satisfied with } \\
\text { frequency of } \\
\text { curriculum review and } \\
\text { revision }\end{array}$ & $\begin{array}{l}\text { Table Value }(0.5) \\
\text { Calculated Values } \\
\text { Null Hypothesis }\end{array}$ & $\begin{array}{c}9.488 \\
30.414 \\
\text { Rejected }\end{array}$ & $\begin{array}{c}9.488 \\
19.729 \\
\text { Rejected }\end{array}$ & $\begin{array}{c}9.488 \\
8.22 \\
\text { Accepted }\end{array}$ & $\begin{array}{c}9.488 \\
22.998 \\
\text { Rejected }\end{array}$ \\
\hline 4 & $\begin{array}{l}\text { Some information in } \\
\text { existing curriculum is } \\
\text { outdated }\end{array}$ & $\begin{array}{c}\text { Table Value }(0.5) \\
\text { Calculated Values } \\
\text { Null Hypothesis }\end{array}$ & $\begin{array}{c}9.488 \\
35.816 \\
\text { Rejected }\end{array}$ & $\begin{array}{c}9.488 \\
61.391 \\
\text { Rejected }\end{array}$ & $\begin{array}{c}9.488 \\
19.776 \\
\text { Rejected }\end{array}$ & $\begin{array}{c}9.488 \\
11.498 \\
\text { Rejected }\end{array}$ \\
\hline 5 & $\begin{array}{l}\text { Teaching methodology } \\
\text { creates lack of interest } \\
\text { among students }\end{array}$ & $\begin{array}{c}\text { Table Value }(0.5) \\
\text { Calculated Values } \\
\text { Null Hypothesis }\end{array}$ & $\begin{array}{c}9.488 \\
82.31 \\
\text { Rejected }\end{array}$ & $\begin{array}{c}9.488 \\
102.483 \\
\text { Rejected }\end{array}$ & $\begin{array}{c}9.488 \\
37.109 \\
\text { Rejected }\end{array}$ & $\begin{array}{c}9.488 \\
5.498 \\
\text { Accepted }\end{array}$ \\
\hline 6 & $\begin{array}{l}\text { Involvement of } \\
\text { teachers is essential, } \\
\text { while revising } \\
\text { curriculum }\end{array}$ & $\begin{array}{c}\text { Table Value }(0.5) \\
\text { Calculated Values } \\
\text { Null Hypothesis }\end{array}$ & $\begin{array}{c}9.488 \\
374.958 \\
\text { Rejected }\end{array}$ & $\begin{array}{c}9.488 \\
104.482 \\
\text { Rejected }\end{array}$ & $\begin{array}{c}9.488 \\
31.776 \\
\text { Rejected }\end{array}$ & $\begin{array}{c}9.488 \\
31.332 \\
\text { Rejected }\end{array}$ \\
\hline 7 & $\begin{array}{l}\text { Need constant review } \\
\text { and updating }\end{array}$ & $\begin{array}{c}\text { Table Value }(0.5) \\
\text { Calculated Values } \\
\text { Null Hypothesis }\end{array}$ & $\begin{array}{c}9.488 \\
562.153 \\
\text { Rejected }\end{array}$ & $\begin{array}{c}9.488 \\
106.846 \\
\text { Rejected }\end{array}$ & $\begin{array}{c}9.488 \\
34.221 \\
\text { Rejected }\end{array}$ & $\begin{array}{c}9.488 \\
30.498 \\
\text { Rejected }\end{array}$ \\
\hline 8 & $\begin{array}{l}\text { Can influence stability } \\
\text { and sustainability of } \\
\text { society }\end{array}$ & $\begin{array}{c}\text { Table Value }(0.5) \\
\text { Calculated Values } \\
\text { Null Hypothesis }\end{array}$ & $\begin{array}{c}9.488 \\
815.011 \\
\text { Rejected }\end{array}$ & $\begin{array}{c}9.488 \\
102.24 \\
\text { Rejected }\end{array}$ & $\begin{array}{c}9.488 \\
39.332 \\
\text { Rejected }\end{array}$ & $\begin{array}{c}9.488 \\
10.832 \\
\text { Rejected }\end{array}$ \\
\hline
\end{tabular}

As the above table shows, majority of the teachers and students think that curriculum do not give information about current pedagogical aspects nor comparable to international standards in terms of knowledge and skills neither methodology creates interest among students. Both teachers and students are not satisfy with the frequency of revision of curriculum as information in existing curriculum is out dated so it needs constant revision to get stability and sustainability in society as well as to meet the challenges of today's world and to do so teacher's involvement is essential for the required results.

\section{Conclusion}

Globalization has entirely changed the nature of both international competition and local survival for Individuals, for communities as well as for nations. The job market is being internationalized and without appropriate abilities, skills and competences there is no hope to get respectable place in working areas. As our only means to be successful lives in quality education, so 
the need to have a robust progressive curriculum is essential. A curriculum is the backbone of any educational system and a tool that helps educational institutions achieve their objectives. Therefore it constantly needs to be reviewed and revised to make this tool more useful for the students and to evaluate the instructional topics. This process is fundamental to all subjects across all grades especially for the subject of Education as it is the foundation of entire teachinglearning system. The instructional topics taught in this subject do not still fully meet the quality standard of international educational world as some of the topics are out-dated and redundant while others have the information gaps. The data also indicates dissatisfaction from both teachers and students on the knowledge and skills provided to students studying Education at graduate level. Further to this the topics fail to meet the expectation of developing productive individuals and successful professionals to contribute to the progress of the nation. Beside the methodology and teaching approach of these topics, there is a need to introduce new instructional topics as well as updating of existing topics. As we know curriculum is said to be throbbing pulse of a nation, one can judge the state of intellectual development and the progress of a nation by looking at it, so it should be constant review and revised with careful and practical approach.

\section{Recommendations}

Curriculum review and revision is a continuous process therefore, the Bureau should ensure that a regular review cycle is followed. Reviews are usually performed at end of 3 to 5 years in most cases with annual data collection to develop pattern of impact.

The learning outcomes of subject Education at graduate level and above should align with expectations of education policies to have productive, creative and confident individuals positively contributing to the progress of country. The topics should lead to critical thinking, creativity and leadership along with values among students.

Entrepreneurial education should be part of the curriculum to develop self-directed, business skills in students for them to be independent in making choices for themselves.

The Curriculum Bureau should involve all stakeholders in the review process. Apart from subject experts in Education, members of Ministry of Education, and administrators, the Bureau should involve teachers and students as well. At the time of initiating this review, there should be several brainstorming sessions with these stakeholders to understand and identify needs and expectations.
Subject of education is a combination of theoretical and field-based course. Thus the course approach should be made interactive, reflective and comparative. The content should include case studies method, field-based projects and small-scale researches to develop better understanding of the scope and application of Education among students. These skills equip students to assess and analyze issues and suggest solutions and remedies keeping in mind the local and global context.

The subject of education should include a separate section of International and Comparative Education to give students a broader perspective and cultivate alternative thinking. This helps in acquainting them to latest trends and technologies and their applications and to have improved, comprehensive understanding of the educational systems of past and present.

Regular conferences, seminars and workshops with local as well as international experts should be arranged for the teachers, teaching Education as a subject both at public and private institutions to help them keep abreast with modern day trends and researches and become better professionals.

The instructional topics at graduate level should be according to the need of our society as well as global job market and economy. These must be selected with professional thoroughness and diligence, keeping national and international standards in view.

\section{References}

Alemi, M., Sarab, M. \& Lari, Z. (2012). Successful learning of academic word list via MALL: Mobile Assisted Language Learning. The Canadian Center of Science and Education. International Education Studies, 5(6), 99-109. Retrieved from http://www.ccsenet.org.

Aslam, S.P. (2005). Education in Pak-Policies formulation, National Book Foundation, Ministry of Education Islamabad.

Beauchamp, G.A. (1968). Curriculum Theory. Illinois: Kagg Press.

Chavan, S. (2003) Education for all: Promises and progress. New Delhi: Rajat Publishing.

Dash, B.N., (2007) Curriculum planning and Development. New Delhi: Dominant Publishers.

Ediger, M. (2007). Curriculum of school subjects. Discovery Publishing House.

Isani, U.A.G. and M.L. Virk. 2003. Higher Education in Pakistan: A historic and futuristic perspective. Islamabad, Pakistan: National Book Foundation.

Kerr, J.F. (1968). Changing the Curriculum. University of London Press. 
Marsh, C.J. (1995). Curriculum: Alternative approaches, ongoing issues. New Jersey: Prentice Hall.

Massie, W.W. (2002). Curriculum revision in the light of ABET 2000 criteria. Research Paper on http://fieconference.org/fie2002/papers/1233.pdf

McGee, C. (1997). Teachers and curriculum decisionmaking. Palmerston North, New Zealand: Dunmore.

Purkait, B.R. (2005). Principles and Practice of Education. Kolkatta: New Central Book Agency Pvt. Ltd.

Raymont, T. (2005). Modern Education: Its aims and Method. New Delhi: Dominant Publishers. 